\title{
Isolation of phyllosilicate-iron redox cycling microorganisms from an illite-smectite rich hydromorphic soil
}

\author{
Evgenya Shelobolina*, Hiromi Konishi, Huifang Xu, Jason Benzine, Mai Yia Xiong, Tao Wu, Marco Blöthe \\ and Eric Roden
}

Department of Geoscience, University of Wisconsin-Madison, Madison, WI, USA

\section{Edited by:}

David Emerson, Bigelow Laboratory

for Ocean Sciences, USA

\section{Reviewed by:}

Kirsten Küsel, Friedrich-Schiller-

University Jena, Germany

Nicole Posth, University of Southern

Denmark, Denmark

*Correspondence:

Evgenya Shelobolina, Department of Geoscience, University of

Wisconsin-Madison, 1215 West

Dayton Street, Madison, WI 53706,

USA.

e-mail: shelobolina@wisc.edu
The biogeochemistry of phyllosilicate-Fe redox cycling was studied in a Phalaris arundinacea (reed canary grass) dominated redoximorphic soil from Shovelers Sink, a small glacial depression near Madison, WI. The clay size fraction of Shovelers Sink soil accounts for $16 \%$ of the dry weight of the soil, yet contributes $74 \%$ of total Fe. The dominant mineral in the clay size fraction is mixed layer illite-smectite, and in contrast to many other soils and sediments, Fe(III) oxides are present in low abundance. We examined the Fe biogeochemistry of Shovelers Sink soils, estimated the abundance of Fe redox cycling microorganisms, and isolated in pure culture representative phyllosilicate-Fe oxidizing and reducing organisms. The abundance of phyllosilicate-Fe reducing and oxidizing organisms was low compared to culturable aerobic heterotrophs. Both direct isolation and dilution-to-extinction approaches using structural $\mathrm{Fe}(\mathrm{II})$ in Bancroft biotite as a $\mathrm{Fe}(\mathrm{II})$ source, and $\mathrm{O}_{2}$ as the electron acceptor, resulted in recovery of common rhizosphere organisms including Bradyrhizobium spp. and strains of Cupriavidus necator and Ralstonia solanacearum. In addition to oxidizing biotite and soluble $\mathrm{Fe}(\mathrm{II})$ with $\mathrm{O}_{2}$, each of these isolates was able to oxidize $\mathrm{Fe}(\mathrm{II})$ in reduced NAu2 smectite with $\mathrm{NO}_{3}^{-}$as the electron acceptor. Oxidized NAu-2 smectite or amorphous Fe(III) oxide served as electron acceptors for enrichment and isolation of Fe(III)-reducing microorganisms, resulting in recovery of a strain related to Geobacter toluenoxydans. The ability of the recovered microorganisms to cycle phyllosilicate-Fe was verified in an experiment with native Shovelers Sink clay. This study confirms that Fe in the native Shovelers Sink clay is readily available for microbial redox transformation and can be cycled by the $\mathrm{Fe}(\mathrm{III})$-reducing and Fe(II)-oxidizing microorganisms recovered from the soil.

Keywords: smectite, phyllosilicate, Fe(III) reducing microorganisms, Fe(II) oxidizing microorganisms, neutrophilic, soil, hydromorphic, Shovelers Sink

\section{INTRODUCTION}

Clay size Fe-bearing phyllosilicate phases, along with $\mathrm{Fe}(\mathrm{III})$ hydroxides, play a central role in the Fe redox biogeochemistry in natural environments (Amonette, 2002). These two groups of Fe-bearing minerals have contrasting geochemical behavior. Reduction of $\mathrm{Fe}(\mathrm{III})$ hydroxides typically results in $\mathrm{Fe}(\mathrm{II})$ mobilization, with the potential for redistribution of Fe via diffusion/dispersion and pore fluid advection. In contrast, structural $\mathrm{Fe}$ in clay minerals can undergo multiple redox cycles without being mobilized, because Fe remains within the mineral structure and within the system (Dong et al., 2009; Stucki, 2011). Multiple $\mathrm{Fe}(\mathrm{III})$ hydroxide reducing and soluble $\mathrm{Fe}(\mathrm{II})$-oxidizing organisms are available as model microbial agents (Lovley et al., 2004; Weber et al., 2006; Emerson et al., 2010; Schmidt et al., 2010; Konhauser et al., 2011). Much less is known about microorganisms involved in phyllosilicate-Fe redox cycling. When $10 \mathrm{Fe}(\mathrm{III})-$ reducing organisms [enriched and isolated with $\mathrm{Fe}(\mathrm{III})$ hydroxide as the sole electron acceptor] were tested for growth on a model ferruginous smectite, only eight could reduce structural $\mathrm{Fe}(\mathrm{III})$ in the smectite (Kashefi et al., 2008). These findings suggest that
phyllosilicate-Fe(III)-reducing and $\mathrm{Fe}(\mathrm{III})$ (hydr)oxide-reducing microbial populations may not always overlap. Even less is known about organisms capable of oxidizing structural $\mathrm{Fe}(\mathrm{II})$ in smectite. The only culture known to catalyze this reaction is a strain of Desulfitobacterium hafniense (formerly D. frappieri) isolated from a subsurface smectite bedding, which is capable of $\mathrm{NO}_{3}^{-}$-dependent structural Fe(II) oxidation (Shelobolina et al., 2003).

The coexistence and aggregation of Fe-bearing phyllosilicates and $\mathrm{Fe}$ (III) hydroxides makes it challenging to study the redox cycling of phyllosilicate-Fe in many soils and sediments. Certain non-highly weathered soils, however, may be enriched in phyllosilicates relative to $\mathrm{Fe}$ and $\mathrm{Al}$ oxides (Brady and Weil, 2008). The loess-derived silty clay loam deposits at Shovelers Sink, near Madison, WI, USA (Clayton and Attig, 1997; Bradbury, 2001) provide an excellent example of this type of soil environment. Shovelers Sink is a small, permanent, remnant glacial depression which originated as a proglacial lake fed by water draining off ice when glaciers covered the Madison area about 15,000 years ago (Clayton and Attig, 1997; Bradbury, 2001). At present Shovelers Sink is a wetland managed as a wildlife conservancy area. The dominant 
plant species at Shovelers Sink is Phalaris arundinacea (reed canary grass, RCG), which forms a dense, up to $1 \mathrm{~m}$ deep root system that is tolerant to prolonged anoxia during times of soil saturation (Barclay and Crawford, 1983). The redoximorphic conditions and high abundance of Fe-bearing phyllosilicates relative to $\mathrm{Fe}$ (III) oxides makes Shovelers Sink an ideal setting to study the biogeochemistry of phyllosilicate-Fe redox cycling. The aim of this study was to characterize the biogeochemistry and mineralogy of Shovelers Sink soil, and to enumerate and isolate microorganisms capable of reducing or oxidizing phyllosilicate-Fe.

\section{MATERIALS AND METHODS STUDY SITE AND SAMPLE COLLECTION}

Soil and groundwater samples were collected from Shovelers Sink site located in the Cross Plains unit of the Ice Age National Scientific Reserve, c.a. $50 \mathrm{~m}$ from Mineral Point Road and $17 \mathrm{~m}$ from the pond. Soils were collected (January 2007, July 2007, June 2008, and September 2009) with a stainless steel coring device. Fluid from below the water table was collected in $50-\mathrm{ml}$ plastic tubes. Core sections were placed in sterile sample collection plastic bags and immediately delivered to the laboratory. All core sections were placed into an anaerobic chamber filled with $\mathrm{N}_{2}: \mathrm{H}_{2} \operatorname{mix}(95: 5)$, homogenized, and dispensed into serum bottles or pressure tubes for immediate experimentation, or into large Pyrex bottles with thick rubber stoppers for storage and/or later use. After removal from the anaerobic chamber, all bottles were flushed with $\mathrm{O}_{2}$-free $\mathrm{N}_{2}$ (passed over reduced, hot copper filings) to remove $\mathrm{H}_{2}$ from the headspace. Soil water was filtered through a $0.2-\mu \mathrm{m}$ syringe filter and frozen prior to analysis by ion chromatography.

\section{SEPARATION AND ANALYSIS OF GRAIN SIZE FRACTIONS}

Soils were size fractionated by wet-sieving and centrifugation (Jackson, 1969; Gee and Bauder, 1986). Wet-sieving was performed in the anaerobic chamber using water made anoxic by bubbling with $\mathrm{N}_{2} .1000 \mathrm{ml}$ Pyrex bottles containing $900 \mathrm{ml}$ water each were bubbled for $2 \mathrm{~h}$. No gravel size particles $(>2 \mathrm{~mm})$ were found in the materials. Sand $(50 \mu \mathrm{m}-2 \mathrm{~mm})$ size materials were removed by sieving (USA Standard Testing Sieves, VWR Scientific). The remaining silt $(2 \mu \mathrm{m}-50 \mu \mathrm{m})$ and clay $(<2 \mu \mathrm{m})$ grain size fractions were separated by centrifugation in sealed plastic bottles under $\mathrm{N}_{2}$. The settling time for the clay size fraction was calculated for a particle density of $2.6 \mathrm{~g} / \mathrm{cm}^{3}$ using Stokes' Law. A small portion of each size fraction was used to determine the dry weight per unit volume of soil suspension. These subsamples were dried at $105^{\circ} \mathrm{C}$ and wet/dry sample weight factors were calculated from weight differences before and after drying.

Total $\mathrm{Fe}(\mathrm{II})$ and $\mathrm{Fe}(\mathrm{III})$ in the size fractions was determined by the hydrofluoric acid (HF) extraction followed by the 1,10Phenanthroline assay as described by Stucki (1981) and modified by Komadel and Stucki (1988). Fe(III) oxyhydroxide contents were determined by citrate-bicarbonate-dithionite (CDB) extraction (Mehra and Jackson, 1980) and ferrozine analysis (Stookey, 1970). All Fe measurements were performed in triplicate. Organic carbon was measured with a Leco CHN analyzer at the UW-Madison Soil and Plant Analysis Laboratory.

\section{DETERMINATION OF STEADY STATE $\mathrm{H}_{2}$ CONCENTRATIONS}

To determine steady state dissolved $\mathrm{H}_{2}$ concentration in the porewater within representative soil samples, c.a. $30 \mathrm{~g}$ of each sample were placed into $60 \mathrm{ml}$ serum bottles under an $\mathrm{N}_{2}$ atmosphere. $\mathrm{H}_{2}$ concentration in the headspace was monitored over time with a reduction gas analyzer (ta3000 Gas Analyzer, Trace Analytical, Ametek) until stability was reached.

\section{TRANSMISSION ELECTRON MICROSCOPY}

Transition electron microscopy (TEM) analyses were carried out using a FEI Titan 80-200 aberration corrected scanning/transmission electron microscope associated with an EDAX AMETEK high resolution energy-dispersive X-ray spectroscopy (EDS) detector and Gatan image filtering system, and operated at $200 \mathrm{kV}$. The samples were mixed with distilled water and ultrasonicated for $\sim 3 \mathrm{~min}$. A drop of the resulting suspension was placed on a lacey-carbon coated $\mathrm{Cu}$ grid and air-dried.

\section{X-RAY DIFFRACTION}

X-ray diffraction (XRD) analyses were done using a Scintag Pad $\mathrm{V}$ Diffractometer with $\mathrm{CuK} \alpha$ radiation. The instrument used an accelerating voltage of $45 \mathrm{kV}$, a current of $40 \mathrm{~mA}$, a 2-mm divergence slit, 4-mm incident scatter slit, 1-mm diffracted beam scatter slit, and $0.5-\mathrm{mm}$ receiving slit. Scan parameters used were a step size of $0.02^{\circ}$ and a dwelling time of $2 \mathrm{~s}$. Oriented aggregate mounts were prepared by pasting clay-DI water suspension on glass slides and air drying. A drop of ethylene glycol was added directly to the surface of the oriented clay mount with a glass rod for ethylene glycol treatment. Oriented aggregate mounts were heated at $550^{\circ} \mathrm{C}$ for $3 \mathrm{~h}$ in the furnace for heat treatment.

\section{MOST PROBABLE NUMBER ANALYSIS}

Microorganisms were enumerated by the most probable number (MPN) method (Woomer, 1994). Strict anaerobic laboratory technique (Miller and Wolin, 1974) was used to quantify anaerobic Fe(III)-reducing bacteria. An anaerobic basal bicarbonatebuffered freshwater (FW) medium (Lovley and Phillips, 1988) was dispensed into $27 \mathrm{ml}$ anaerobic pressure tubes (Bellco Glass, Inc.) under $\mathrm{N}_{2} / \mathrm{CO}_{2}(80: 20 \%)$. The tubes were capped with butyl rubber stoppers and sterilized by autoclaving. The medium for $\mathrm{Fe}(\mathrm{III})$-reducing bacteria contained either $100 \mathrm{mM}$ hydrous ferric oxide (HFO) or 0.8 weight $\%$ of the $\mathrm{Fe}(\mathrm{III})$-bearing smectite NAu-2 $\left[\mathrm{M}_{0.72}^{+}\left(\mathrm{Si}_{7.55} \mathrm{Al}_{0.45}\right) \mathrm{Fe}_{3.83} \mathrm{Mg}_{0.05}\right) \mathrm{O}_{20}(\mathrm{OH})_{4}$ where $\mathrm{M}$ is the interlayer cation; Keeling et al., 2000] as a terminal electron acceptor, $\mathrm{H}_{2}$ ( $3 \mathrm{ml}$ filtered $\mathrm{H}_{2}$ was added to the headspace) and acetate $(10 \mathrm{mM})$ as the combined electron donor, and $1.3 \mathrm{mM} \mathrm{FeCl}_{2}$ as a reducing agent. The medium for $\mathrm{Fe}(\mathrm{II})$-oxidizing bacteria contained $\mathrm{O}_{2}$ as the terminal electron acceptor $(3 \mathrm{ml}$ filtered air added to the headspace) and $1.1 \%$ Bancroft (Ward Scientific) biotite $\left[\left(\mathrm{K}_{0.980}, \mathrm{Na}_{0.025} ; \mathrm{Fe}_{0.996}^{2+}, \mathrm{Fe}_{0.222}^{3+} \mathrm{Mg}_{1.663}, \mathrm{Ti}_{0.117} ; \mathrm{Si}_{3.048}, \mathrm{Al}_{0.812}\right.\right.$, $\left.\left.\mathrm{Ti}_{0.140}\right) \mathrm{O}_{10}\left(\mathrm{OH}_{1.02}, \mathrm{~F}_{0.98}\right)\right]$ as a source of structural Fe(II). Aerobic heterotrophic bacteria were enumerated in medium containing (gram per liter) PIPES (piperazine- $N, N^{\prime}$-bis-2-ethanesulfonic acid) buffer (3.0), $\mathrm{NH}_{4} \mathrm{Cl}(0.25), \mathrm{NaH}_{2} \mathrm{PO}_{4} \cdot \mathrm{H}_{2} \mathrm{O}(0.06), \mathrm{KCl}(0.1)$, yeast extract $(0.5)$, and acetate $(0.41)$.

\section{ISOLATION OF Fe(III)-REDUCING ORGANISMS}

Smectite-containing MPN cultures were diluted in agarized medium containing $20 \mathrm{mM}$ fumarate and $20 \mathrm{mM}$ acetate with a roll-tube method (Hungate, 1968). An inoculum (1 ml) from the 10 -fold serial dilutions of the enrichment culture in a liquid FW 
medium was added to $27 \mathrm{ml}$ pressure tubes containing $7 \mathrm{ml}$ melted medium. The contents were mixed gently and the pressure tubes were rolled with a tube spinner. The roll-tubes were incubated vertically at room temperature. Individual colonies were transferred to the pressure tubes with $2 \mathrm{ml}$ liquid $\mathrm{FW}$ medium containing $0.8 \%$ NAu-2 smectite as the electron acceptor and $10 \mathrm{mM}$ acetate as the electron donor.

\section{ISOLATION OF Fe(II)-OXIDIZING ORGANISMS}

Freshly collected samples and highest positive MPN dilution cultures were serially diluted in biotite $/ \mathrm{O}_{2}$-containing roll-tubes. After orange and red colored individual colonies formed, they were transferred to the pressure tubes with 2 ml liquid FW medium containing $1.1 \%$ biotite and $3 \mathrm{ml}$ filtered air. Biotite oxidizing cultures were serially diluted and plated on aerobic heterotrophic medium using $1.5 \%$ agar as the solidifying agent.

Biotite oxidizing cultures were tested for their ability to grow via microaerophilic $\mathrm{FeCl}_{2}$ oxidation. The cultures were grown on a heterotrophic low-organic medium $(0.01 \%$ yeast extract and $1 \mathrm{mM}$ acetate, with $3 \mathrm{ml}$ of filtered air in the headspace), and then transferred ( $5 \% \mathrm{vol} / \mathrm{vol}$ inoculum) to anoxic FW medium, to which $1.3 \mathrm{mM} \mathrm{FeCl}_{2}$ and $1 \mathrm{ml}$ filtered air were added via syringe and needle every other day. After 12 days of cultivation, cell numbers were determined. The aliquots of the culture were fixed with glutaraldehyde. The fixed culture was reacted with ammonium oxalate $(28 \mathrm{~g} / \mathrm{l}$ ammonium oxalate and $15 \mathrm{~g} / \mathrm{l}$ oxalic acid) in the presence of ca. $1 \mathrm{mM} \mathrm{FeCl}_{2}$ to dissolve $\mathrm{Fe}(\mathrm{III})$ hydroxides. Cells were counted by acridine orange staining and epifluorescence microscopy (Hobbie et al., 1977).

\section{MOLECULAR BIOLOGICAL METHODS}

The16S rRNA gene sequences of the isolates and enrichment cultures were obtained using standard methodologies as previously described (Shelobolina et al., 2007). 16S rRNA genes were amplified using GM3 and GM4 primer set (Muyzer et al., 1995). For enrichment cultures 16S rRNA genes were cloned using the pGEM-T vector (Promega). The 16S rRNA gene fragments were compared to the GenBank nucleotide database using BLASTN and BLASTX algorithms (Altschul et al., 1990).

\section{Fe CYCLING EXPERIMENT}

An iron cycling experiment was performed in FW medium supplemented with natural Shovelers Sink clay. The clay suspension was bubbled with air for 1 day to oxidize structural Fe(II), after which the clay was dried and mixed with FW medium prior to bubbling with $\mathrm{N}_{2}: \mathrm{CO}_{2}$ mix and autoclaving. XRD analysis of the clay before and after autoclaving showed no difference suggesting no change in the mineralogy of the clay (data not shown). A small amount of acetate $(0.25 \mathrm{mM})$ was provided as a limited source of electron donor. Eighteen culture tubes were inoculated with $G$. toluenoxidans strain sa2 isolated from Shovelers Sink soil, and three tubes served as abiotic controls. Fe(III) reduction was allowed to proceed for 10 days. Five millimolar $\mathrm{NO}_{3}^{-}$was then added to 12 tubes, and of these tubes nine were inoculated with $\mathrm{Fe}$ (II)-oxidizing isolates with three uninoculated tubes serving as controls. No nitrate or $\mathrm{Fe}(\mathrm{II})$-oxidizing culture were added to three tubes in which $\mathrm{Fe}(\mathrm{III})$ reduction was allowed to proceed for the rest of the experiment. To evaluate the reaction of structural Fe(II) oxidation with nitrite, three remaining tubes with reduced Shovelers Sink clay were reacted with ca $2.0 \mathrm{mM}$ nitrite.

Concentrations of $0.5 \mathrm{~N} \mathrm{HCl}$-extractable $\mathrm{Fe}(\mathrm{II}), \mathrm{NO}_{3}^{-}$, and $\mathrm{NO}_{2}^{-}$were monitored over time. One milliliter of the culture was centrifuged in the anaerobic chamber at $14 \mathrm{~K} \mathrm{rpm}$ for $5 \mathrm{~min}$. The supernatant was collected for $\mathrm{NO}_{3}^{-} / \mathrm{NO}_{2}^{-}$and dissolved $\mathrm{Fe}$ analysis. Samples for $\mathrm{Fe}$ analysis were acidified with $\mathrm{HCl}$. The remaining solids were mixed with $0.5 \mathrm{~N} \mathrm{HCl}$ and extracted for $24 \mathrm{~h}$. $\mathrm{Fe}(\mathrm{II})$ in the $\mathrm{HCl}$ extracts was quantified using the ferrozine assay as previously described (Lovley and Phillips, 1986). Preliminary studies demonstrated that a $24-\mathrm{h} 0.5 \mathrm{~N} \mathrm{HCl}$ extraction released the same amount of $\mathrm{Fe}$ (II) from Shovelers Sink clay as HF extraction (Stucki, 1981). Note that this equivalence applies only to $\mathrm{Fe}(\mathrm{II})$, as only a small portion of structural $\mathrm{Fe}(\mathrm{III})$ is extracted by $0.5 \mathrm{~N} \mathrm{HCl}$ (Shelobolina et al., 2004). $\mathrm{NO}_{3}^{-}$and $\mathrm{NO}_{2}^{-}$concentrations were measured with a Dionex DX-100 ion chromatograph equipped with a AS4-SC IonPac column. Dissolved Fe concentrations were determined by inductively coupled plasma-optical emission spectroscopy (ICP-OES).

\section{RESULTS AND DISCUSSION BIOGEOCHEMISTRY OF SHOVELERS SINK SOIL}

The soil at Shovelers Sink represents a silt loam interspersed with RCG roots down to the depth of $105 \mathrm{~cm}$ (Figure 1). The depth of the water table ranged from 60 to $80 \mathrm{~cm}$. Soils collected in July 2007 were characterized in detail, at which time the water table was located at c.a. $65 \mathrm{~cm}$ depth (Figure 2).

Organic carbon concentrations were highest within the main root zone above $55 \mathrm{~cm}(1.7-2.5 \%)$, intermediate in the vicinity of the water table (1.0-1.2\%), and lowest below $80 \mathrm{~cm}(0.32-0.41 \%)$ where few, if any, RCG roots were present (Figure 2B). Total HFextractable iron (Figure 2C) concentrations ranged between 196 and $333 \mathrm{mmol} / \mathrm{kg}$ and showed a trend opposite of that for organic carbon, with Fe concentrations being lowest $(166-190 \mathrm{mmol} / \mathrm{kg}$ ) above a depth of $55 \mathrm{~cm}$, intermediate from the water table down to $105 \mathrm{~cm}(230-249 \mathrm{mmol} / \mathrm{kg})$, and highest below $105 \mathrm{~cm} \mathrm{(333-}$ $337 \mathrm{mmol} / \mathrm{kg}$ ). The fraction of total Fe present as Fe(II) was highly

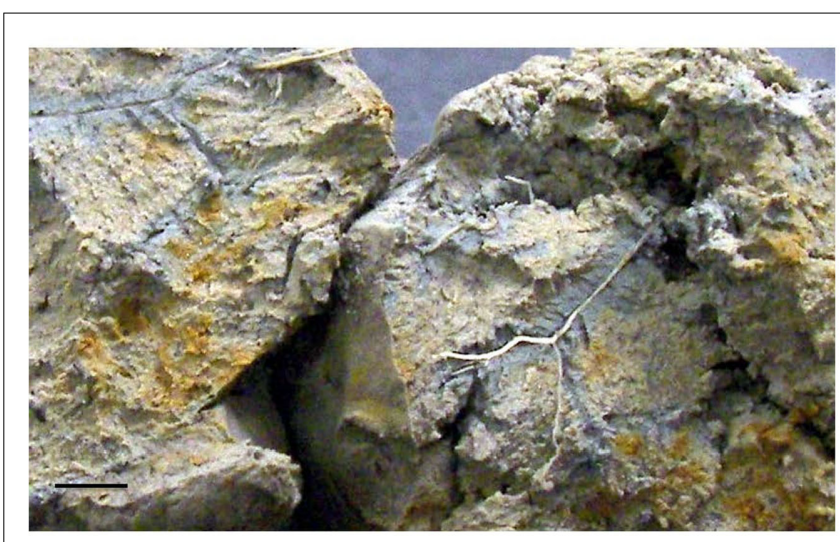

FIGURE 1 | Photograph of Shovelers Sink soil collected in the vicinity of the water table in July 2007, revealing reduced (gray color), and oxidized (bright yellowish-brown colors) regions indicative of redoximorphic conditions. The bar is $1 \mathrm{~cm}$. 


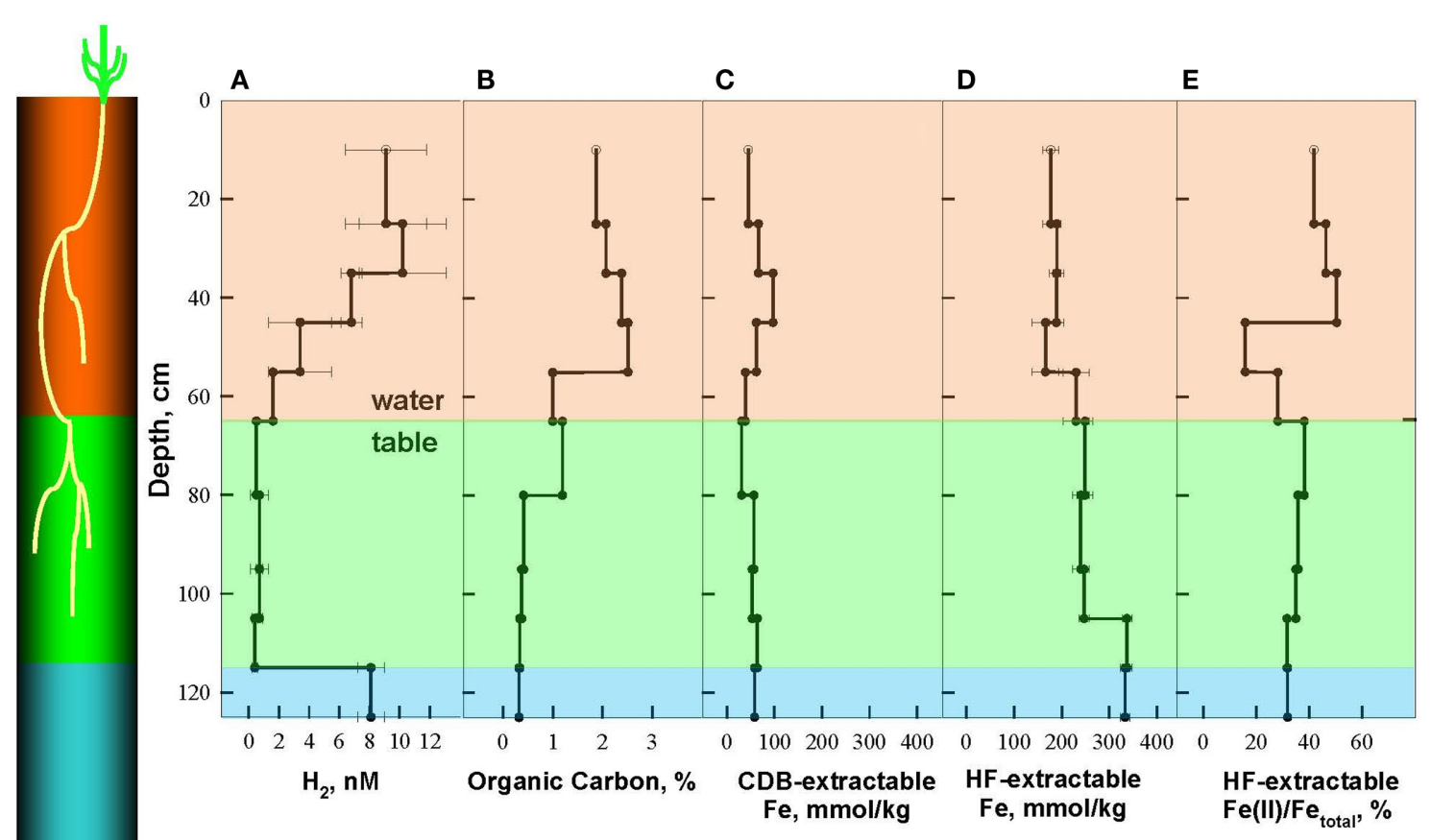

FIGURE 2 | Depth distribution of dissolved $\mathrm{H}_{2}$ (A), Organic Carbon (B), and Fe phases, including citrate-bicarbonate -dithionite (CDB) extractable Fe (C), and hydrofluoric acid (HF)

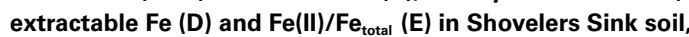

July 2007. A cartoon on the left shows relative depth of root zone and terminal electron accepting processes (TEAPs): brown for mixed metabolism, green for Fe(III)-reducing zone, and blue for methanogenic zone. variable above the water table (16-50\%) and gradually decreased from 38 to $32 \%$ below the water table (Figure 2D).

The spatial segregation of terminal electron accepting processes in Shovelers Sink soil was assessed by measuring steady state concentration of dissolved $\mathrm{H}_{2}$ in incubated soil samples from different depths, according to published criteria (Lovley and Goodwin, 1988; Lovley et al., 1994) and as described in a previous study of clay-rich subsurface sediments (Shelobolina et al., 2004; Figure 2A). Three TEAP zones could be distinguished: a mixed metabolism zone above the water table $(0-65 \mathrm{~cm}$ depth $)$ characterized by a range of $\mathrm{H}_{2}$ concentrations from 1.6 to $10.2 \mathrm{nM}$; a dissimilatory $\mathrm{Fe}(\mathrm{III})$-reducing zone between 65 and $115 \mathrm{~cm}$ characterized by $\mathrm{H}_{2}$ concentrations of $0.4-0.7 \mathrm{nM}$; and a methanogenic zone below $115 \mathrm{~cm}$ with steady state $\mathrm{H}_{2}$ concentration of $8.1 \pm 0.9 \mathrm{nM}$.

Shovelers Sink is a depression in which water balance is maintained through direct precipitation and runoff from the surrounding landscape. Runoff from nearby farms and households could serve as an additional source of both organic carbon and electron acceptors, e.g., $\mathrm{NO}_{3}^{-}$, to the system. However, no $\mathrm{NO}_{3}^{-}$was detected in fluid from below the water table on any of the sampling events. These results suggest that the localized zones of oxidation observed in the soil (see Figure 1) are driven by release of $\mathrm{O}_{2}$ from $\mathrm{RGC}$ roots, as is well-known for a variety of plants that proliferate in water-logged soils (Armstrong, 1978). The observed redoximorphic features (Figure 1) and porewater steady state $\mathrm{H}_{2}$ concentrations (Figure 2A) suggest ongoing Fe redox cycling at two scales: (1) at the centimeter-to-decimeter scale within the transition from saturated/anoxic to unsaturated/partially oxic conditions in the vicinity of the water table; and (2) at the microscale around RCG roots both above and below the water table. Soil from the vicinity of the water table (c.a. 65 depth depth in July 2007) was chosen to study microbial Fe redox cycling as it likely contained both $\mathrm{Fe}(\mathrm{III})$-reducing and $\mathrm{Fe}$ (II)-oxidizing microorganisms.

\section{SOIL MINERALOGY}

Soil collected from the vicinity of the water table in July 2007 was used to study the abundance and mineralogy of Fe in different grain size fractions. The contribution of silt and clay size materials to total dry weight differed dramatically from their contributions to total HF-extractable iron [Fe(II) + Fe(III)] content (Table 1). Although the silt size fraction dominated Shovelers Sink soil by weight ( $83 \%$ of total dry weight), it contributed only $26 \%$ total HF-extractable iron. In contrast, the clay size fraction, which accounted only for $16 \%$ of the dry weight of soil, contributed $74 \%$ of the total HF-extractable iron. These results demonstrate that the majority of the Fe content of Shovelers Sink soil is contained within the clay size fraction.

The mineralogy of silt and clay size fractions was characterized by conventional TEM, high resolution TEM (HRTEM), and XRD (Figures 3-5). The following mineral phases were identified (by TEM) in the silt size fraction: potassium feldspar, plagioclase, quartz, and mixed layered illite-smectite aggregates (Figure 3). Based on TEM and XRD analyses, the dominant mineral in the clay size fraction was illite-smectite mixed layers (Figures 4 and 5). Clay size materials also contained kaolinite and illite as minor components. No Fe(III) hydroxides were detected in either the 
Table 1 | Characterization of silt and clay size fractions of Shovelers Sink soil.

\begin{tabular}{lll} 
Parameter & \multicolumn{2}{c}{ Size fraction } \\
\cline { 2 - 3 } & Clay & Silt \\
\hline \% Dry weight ${ }^{\mathrm{a}}$ & 16 & 83 \\
Dominant minerals $^{\mathrm{b}}$ & illite-smectite & potassium feldspar, \\
& mixed layers, & plagioclase, quartz, \\
& kaolinite, quartz, & and illite-smectite \\
& illite, and $\mathrm{TiO}_{2}$ & aggregates \\
HF-extractable $\mathrm{Fe}, \mathrm{mmol} / \mathrm{kg}$ & $1360.5 \pm 10.7$ & $95.7 \pm 3.3$ \\
\% Total Fe & 74 & 26 \\
CDB-extractable $\mathrm{Fe}, \mathrm{mmol} / \mathrm{kg}$ & $32.7 \pm 1.1$ & $47.4 \pm 2.0$
\end{tabular}

a Percent of total bulk soil dry weight accounted for by the clay or silt size fractions; in addition to silt and clay, Shovelers Sink soil also contains 1\% sand.

${ }^{b}$ Minerals were identified by TEM and XRD analyses and are listed in decreasing order based on their detected content in corresponding size fractions.

cPercent of the total Fe content of bulk soil accounted for by the clay or silt size fractions.

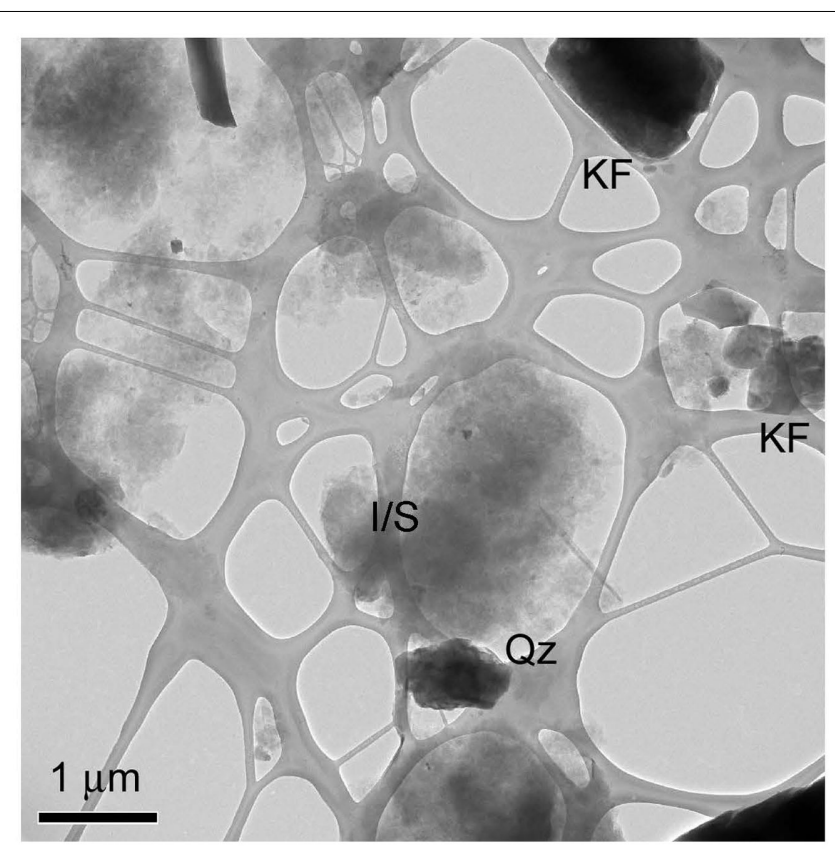

FIGURE 3 |TEM image of Shovelers Sink silt size fraction showing flakes of illite-smectite (I/S), quartz (Oz), and potassium feldspar (KF) grains.

silt or clay size fractions during TEM observations. These results are consistent with CDB extractions, which showed that the abundance of $\mathrm{Fe}$ (III) oxides was ca. less than $5 \%$ of total HF-extractable $\mathrm{Fe}$ in the bulk soil (Figure 2) and less than 2.5\% in the clay size fraction (Table 1). In summary, gravimetric, chemical, and mineralogical analyses collectively suggest that mixed layer illitesmectite is the geochemically dominant Fe-containing phase in Shovelers Sink soil.
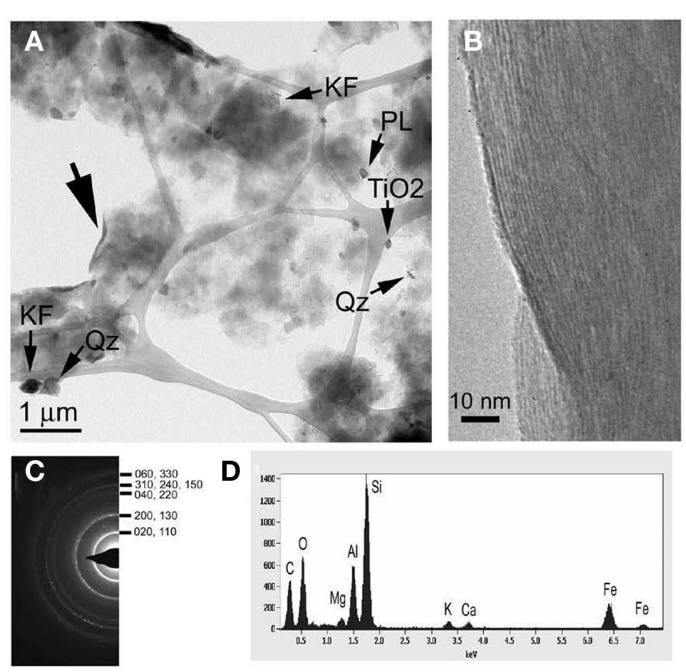

FIGURE 4 | Mineralogy of Shovelers Sink clay size fraction. (A) TEM image showing flakes of smectite-dominated clay minerals (I/S), quartz (Oz), potassium feldspar (KF), plagioclase, and titania $\left(\mathrm{TiO}_{2}\right)$ grains. (B,C) HRTEM image and selected area diffraction pattern taken from the area indicated by the large arrow in (A), showing the curled edge of a clay aggregate with lattice fringes corresponding to (001) smectite with ca. $10-\AA$ layer spacing; the size of this spacing was likely reduced in the vacuum of the TEM. (D) EDAX results for an I/S aggregate. A small amount of potassium is detected, indicating that the smectite contains an illite component.

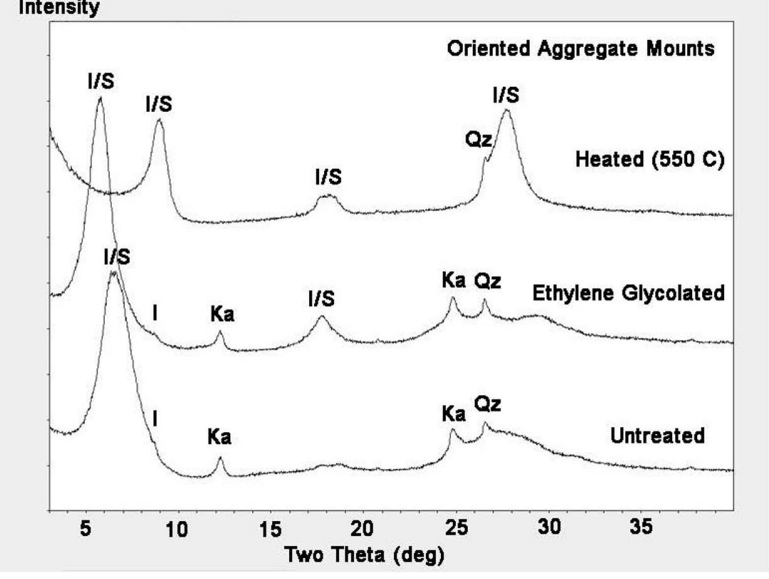

FIGURE 5 | X-ray diffraction analyses of clay size fraction from Shovelers Sink soil showing illite-smectite (I/S) as dominant mineral. Small amounts of illite (I), kaolinite (Ka), and quartz (Qz) also exist. The 13.6- $\AA$ [I/S (001)] peak in the untreated sample expanded to $15.2 \AA$ by ethylene glycol treatment, and collapsed to $9.9 \AA$ by heat treatment. The 7.2- $\AA$ [kaolinite (001)] and 3.6-A [kaolinite (002)] peaks in the untreated sample disappeared by heating at $550^{\circ} \mathrm{C}$.

\section{MPN ENUMERATIONS}

Both $\mathrm{Fe}$ (III)-reducing and $\mathrm{Fe}(\mathrm{II})$-oxidizing microorganisms were detected in MPN enumerations conducted with soil samples from near the water table in July 2007 and in September 2009. 
The abundance of Fe(III)-reducing organisms $\left(2.4 \times 10^{1}\right.$ cells $/ g$ wet soil in 2007 and $2.3 \times 10^{0}$ cells/g wet soil in 2009$)$ and $\mathrm{Fe}(\mathrm{II})$-oxidizing organisms $\left(2.9 \times 10^{2}\right.$ cells/g wet soil in 2007 and $2.4 \times 10^{3}$ cells/g wet soil in 2009) was modest compared to the abundance of total culturable aerobic heterotrophs $\left(1.1 \times 10^{6}\right.$ cells/g wet soil in 2007 and $4.2 \times 10^{5}$ cells/g wet soil in 2009). Analogous results have been reported for groundwater seep environments supporting active Fe redox cycling (Blöthe and Roden, 2009; Roden et al., submitted). Although the much larger densities of culturable aerobic heterotrophs compared to $\mathrm{Fe}$ (III)-reducers in these environments could suggest intense competition between the two physiological groups (e.g., for utilization of plant-derived organic materials), it is important to note that previous studies have shown the persistence of large numbers of aerobic bacteria in permanently anoxic environments (Jorgensen and Tiedje, 1993). Thus, the presence of high densities of culturable aerobes in the Shoveler's sink soil does not necessarily mean that they contribute extensively to in situ carbon metabolism.

\section{Fe(II)-OXIDIZING ISOLATES}

$\mathrm{Fe}(\mathrm{II})$-oxidizing organisms were isolated from (1) soil samples collected in July 2007, June 2008, and September 2009, and (2) the highest positive dilutions from MPN studies set up in 2007 and 2009. Biotite was utilized as a solid phase form of Fe(II) for these studies. Unlike reduced smectite, structural Fe(II) in biotite is not subject to spontaneous reaction with $\mathrm{O}_{2}$, thus permitting the use of $\mathrm{O}_{2}$ as the electron acceptor for lithotrophic $\mathrm{Fe}$ (II) oxidation. Recent studies have demonstrated that the $\mathrm{Fe}(\mathrm{II})$-oxidizing, $\mathrm{NO}_{3}^{-}$ reducing culture described by Straub et al. (1996) can utilize Fe(II) in biotite as a sole electron donor for chemolithotrophic growth (Shelobolina et al., submitted). Samples and last positive MPN dilution cultures were serially diluted in biotite-containing rolltubes. After solidification $3 \mathrm{ml}$ of filter sterilized air were added to the headspace. Roll-tubes were incubated vertically at $20-22^{\circ} \mathrm{C}$ (room temperature). Over a period of 4-8 months, small (0.2$0.5 \mathrm{~mm}$ ) orange, or in some cases red, colonies formed between the layer of biotite and the layer of agarized medium in a roll-tube. Each colony was transferred to $2 \mathrm{ml}$ liquid medium with biotite provided as the electron donor and $\mathrm{O}_{2}$ as the electron acceptor. $\mathrm{A}$ protracted (4 years) isolation effort (2007-2010) resulted in recovery of 73 biotite oxidizing cultures, which were maintained on liquid medium with biotite and $\mathrm{O}_{2}$. Eleven cultures capable of oxidizing at least $5 \%$ of the structural $\mathrm{Fe}$ (II) content in biotite were selected for further study. Culture subsamples were streaked onto aerobic, low carbon medium culture plates. The resulting isolated colonies could be either mixotrophic Fe(II)-oxidizing microorganisms or heterotrophic contaminants. The numerically dominant colony types were tested for microaerophilic growth with $\mathrm{FeCl}_{2}$ as a soluble $\mathrm{Fe}(\mathrm{II})$ sources. Cultures capable of growing to a density of at least $10^{8}$ cells $/ \mathrm{ml}$ with a total of c.a. $8 \mathrm{mM} \mathrm{FeCl}_{2}$ added over time (see Materials and Methods) were identified by $16 \mathrm{~S}$ rRNA gene sequencing and selected for further study. The isolates so obtained included Bradyrhizobium spp., and strains of Ralstonia solanacearum, and Cupriavidus necator. One strain each was chosen for further study (Table 2). Each of the cultures oxidized $3-4 \%$ of structural $\mathrm{Fe}(\mathrm{II})$ in biotite with $\mathrm{O}_{2}$ as the electron acceptor, and each was found to be capable of oxidizing chemically reduced smectite with $\mathrm{NO}_{3}^{-}$as the electron acceptor (data not shown).

\section{Fe(III)-REDUCING ISOLATE}

Ferruginous NAu-2 smectite and hydrous ferric oxide (HFO) were used to enrich $\mathrm{Fe}$ (III)-reducing microorganisms from Shovelers Sink soil collected in July 2007 with acetate and $\mathrm{H}_{2}$ as combined electron donors. Acetate and $\mathrm{H}_{2}$ were used as these represent the two major sources of electron donor for microbial Fe(III) reduction in anoxic soils and sediments (Lovley et al., 2004). After ca. 2 months of room temperature incubation, small (25 clones each) $16 \mathrm{~S}$ rRNA gene clone libraries were constructed from $1 \%$ enrichment cultures. Both enrichment cultures were dominated by an operational taxonomic unit (OTU) $99 \%$ similar to Geobacter toluenoxydans (Kunapuli et al., 2010). G. toluenoxydans strain sa2 was recovered using the roll-tube method with acetate as the electron donor and fumarate as the electron acceptor. Strain sa 2 can conserve energy from dissimilatory $\mathrm{Fe}$ (III) reduction concomitant with acetate oxidation using a variety of solid phase $\mathrm{Fe}$ (III) sources, including Fe(III) hydroxide and ferruginous smectite, but does not utilize nitrate as the electron acceptor.

\section{MICROBIAL REDOX CYCLING OF Fe IN SHOVELERS SINK CLAY}

A Fe redox cycling experiment was conducted with clay size materials isolated from Shovelers Sink soil collected from ca. $65 \mathrm{~cm}$ depth in July 2007 (see Table 1). Although $\mathrm{O}_{2}$ is a likely electron acceptor for microbial Fe(II) oxidation at Shovelers Sink (see above), $\mathrm{NO}_{3}^{-}$was utilized in this model experiment since it does

Table 2 | Fe redox cycling microorganisms isolated from Shovelers Sink soil.

\begin{tabular}{|c|c|c|c|}
\hline Strain & GenBank accession \# & Identification (closest cultured bacterium, $\%$ identity) & Role in Fe cycle \\
\hline wss 14 & JQ655459 & $\begin{array}{l}\text { Bradyrhizobium liaoningense } 2281^{\top}, 99.6 \% \\
\text { Bradyrhizobium japonicum USDA } 6^{\top}, 99.4 \%\end{array}$ & Fe(II) oxidation \\
\hline in4ss52 & J0655458 & Ralstonia solanacearum LMG 2299', 98.7\% & Fe(II) oxidation \\
\hline
\end{tabular}

The $\%$ values indicate the degree of similarity in 16S rRNA gene sequence. 
not react spontaneously with phyllosilicate-associated $\mathrm{Fe}(\mathrm{II}) . \mathrm{G}$. toluenoxidans strain sa2 (5\% vol/vol inoculum from a culture grown previously for three transfers on limiting acetate/Shovelers Sink clay medium, providing c.a. $10^{6}$ cells $/ \mathrm{ml}$ ) reduced $2.1 \mathrm{mmol} / 1$ $\mathrm{Fe}$ (II) over 7 days (Figure 6A). A small increase in aqueous Fe concentration was detected in both abiotic control and the $\mathrm{Fe}(\mathrm{III})$-reducing cultures (35.4 and $50.6 \mu \mathrm{M}$, respectively). The source of dissolved $\mathrm{Fe}$ cannot be determined with available data. Shovelers Sink clay is a mix of minerals. And although illitesmectite is the main Fe-bearing mineral controlling Fe biogeochemistry in Shovelers Sink soil, the clay size fraction could contain organics-bound or sorbed Fe, as well as small amounts of Fe(III) hydroxide coatings. All of these Fe forms could contribute to aqueous Fe.

After 10 days, an inoculum of each of the three $\mathrm{Fe}(\mathrm{II})$ oxidizing isolates (Table 2) were added to replicate microbially reduced clay suspensions. The $\mathrm{Fe}(\mathrm{II})$-oxidizing inocula (1-5\% $\mathrm{vol} / \mathrm{vol}$ ) were grown heterotrophically on organics limited $\mathrm{NO}_{3}^{-}$ reducing medium until the optical density of the culture at $600 \mathrm{~nm}$ stabilized, at which point all organic carbon had presumably been utilized. The inoculum volume was adjusted to provide ca $10^{6}$ cells $/ \mathrm{ml}$. The cultures reoxidized $60-65 \%$ (c.a. $1.2 \mathrm{mmol} / \mathrm{l}$ ) of the $\mathrm{Fe}(\mathrm{II})$ generated by $\mathrm{G}$. toluenoxidans strain sa2 (Figure 6A) while consuming $0.82-1.15 \mathrm{mM} \mathrm{NO}_{3}^{-}$(Figure 6B).

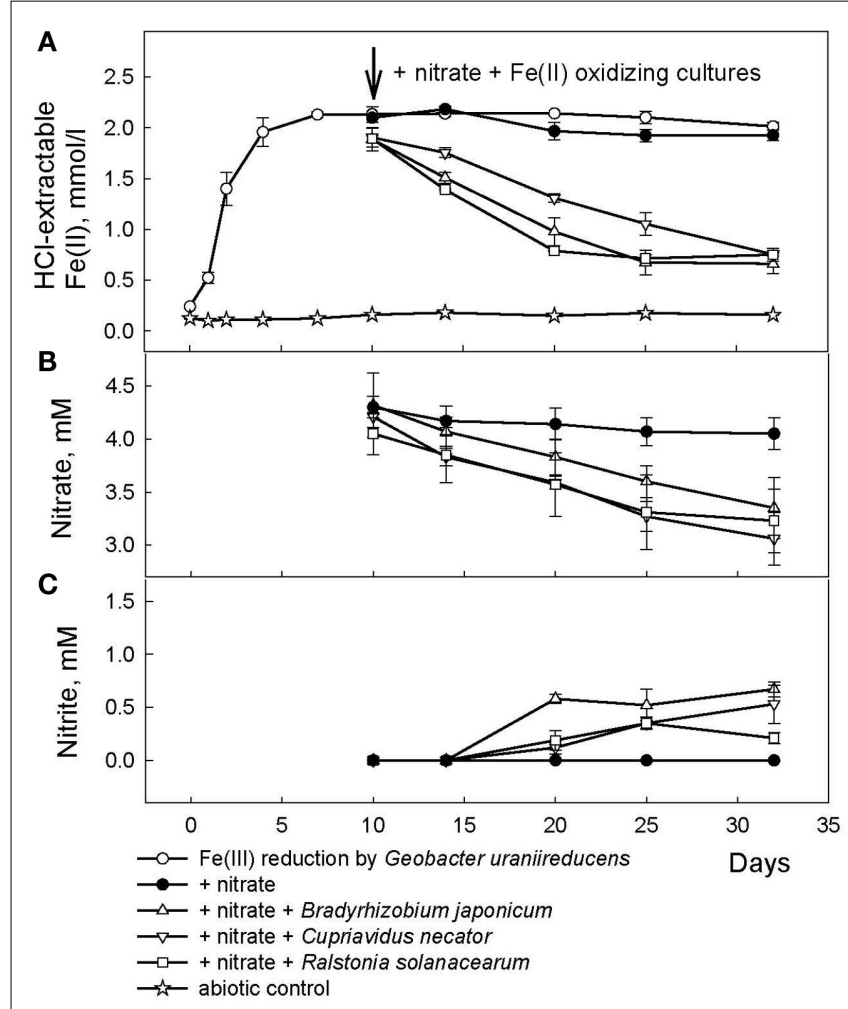

FIGURE 6 | Reduction of native Fe(III) phyllosilicate in Shovelers Sink soil (clay size fraction) by $G$. toluenoxidans strain sa2, followed by oxidation of reduced phyllosilicate by the three $\mathrm{Fe}$ (II)-oxidizing isolates with $\mathrm{NO}_{3}^{-}$as the electron acceptor. (A) $0.5 \mathrm{~N} \mathrm{HCl}$-extractable $\mathrm{Fe}(\mathrm{II})$; (B) nitrate; (C) nitrite.
The incomplete reversibility of structural Fe redox cycle has been observed before (Shen and Stucki, 1994) and a possible explanation for this phenomenon is that the collapsing of smectite layers as the result of $\mathrm{Fe}(\mathrm{III})$ reduction makes a portion of structural $\mathrm{Fe}(\mathrm{II})$ inaccessible (Stucki, 2011).

No $\mathrm{Fe}(\mathrm{II})$ oxidation or $\mathrm{NO}_{3}^{-}$consumption took place in absence of $\mathrm{Fe}$ (II)-oxidizing organisms. Although all of the $\mathrm{Fe}(\mathrm{II})$ oxidizing isolates are denitrifying bacteria, substantial amounts of $\mathrm{NO}_{2}^{-}(0.35-0.67 \mathrm{mM})$ were produced during $\mathrm{Fe}(\mathrm{II})$ oxidation (Figure 6C). The Shovelers Sink soil used in the Fe cycling experiment contained $1-2 \%$ associated organic carbon (see Figure 2). The possibility therefore existed that $\mathrm{NO}_{2}^{-}$produced during organotrophic oxidation of associated organic carbon could have reacted chemically (abiotically) with $\mathrm{Fe}(\mathrm{II})$ in the reduced clay, thereby contributing to the $\mathrm{Fe}(\mathrm{II})$ oxidation activity shown in Figure 6A. We deemed this pathway unlikely given that each of the isolated strains reduced nitrate directly to $\mathrm{N}_{2}$ with no significant $\mathrm{NO}_{2}^{-}$accumulation in organotrophic medium (data not shown). Nevertheless, a separate experiment was conducted to evaluate the extent to which reaction of $\mathrm{Fe}(\mathrm{II})$ with $\mathrm{NO}_{2}^{-}$may have been responsible for the observed $\mathrm{Fe}(\mathrm{II})$ oxidation. Nitrite $(2 \mathrm{mM})$ was added to a suspension of microbially reduced Shovelers Sink clay, and the concentrations of $\mathrm{Fe}(\mathrm{II})$ and $\mathrm{NO}_{2}^{-}$were followed over time (Figure 7). The rate of chemical $\mathrm{Fe}$ (II) oxidation by nitrite (c.a. $0.018 \mathrm{mmol} / \mathrm{l} / \mathrm{day}$; Figure 7) was three to six times less than the rate of oxidation in the microbial Fe cycling experiment $(0.058$ $0.118 \mathrm{mmol} / \mathrm{l} /$ day; Figure $6 \mathrm{~A}$ ). This result indicates that enzymatic activity was primarily responsible for nitrate-dependent

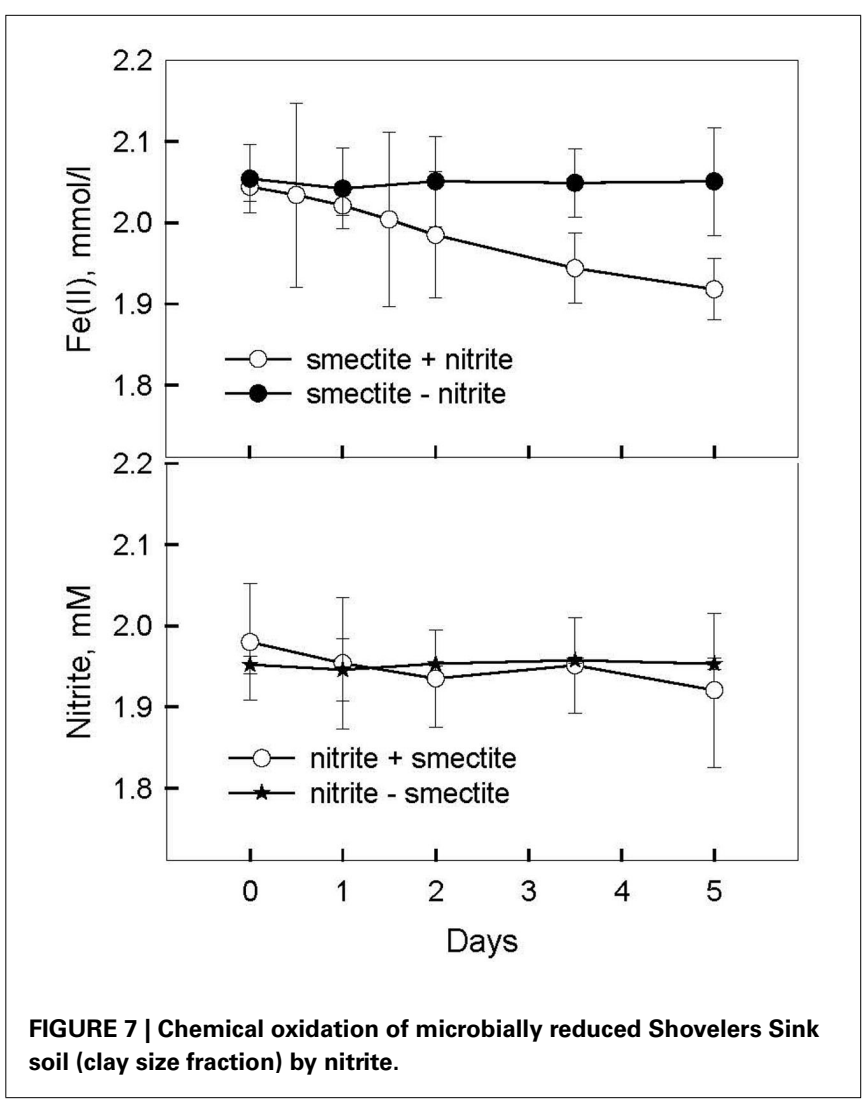


oxidation of reduced Shovelers Sink clay. Similar conclusions were reached in a prior study of microbial nitrate-dependent oxidation of other types of solid phase $\mathrm{Fe}(\mathrm{II})$ compounds in which significant accumulation of $\mathrm{NO}_{2}^{-}$took place (Weber et al., 2001). Thus, although the organic matter associated with Shovelers Sink clay brings uncertainty into the exact stoichiometry of $\mathrm{Fe} / \mathrm{N}$ interactions, the results of this experiment clearly confirm that Fe in the native Shovelers Sink clay is readily available for microbial redox transformation and can be cycled by the Fe(III)reducing and $\mathrm{Fe}(\mathrm{II})$-oxidizing microorganisms recovered from the soil.

\section{IMPLICATIONS FOR PHYLLOSILICATE-Fe BIOGEOCHEMISTRY}

Our studies confirm the presence of both phyllosilicate-Fe(III)reducing and phyllosilicate-Fe(II)-oxidizing organisms in a redoximorphic soil, the biogeochemical conditions of which are consistent with ongoing phyllosilicate-Fe redox cycling in the vicinity of the water table and $\mathrm{O}_{2}$-releasing plant roots. Several solid phase Fe redox cycling isolates were recovered from this soil using model $\mathrm{Fe}(\mathrm{II})$ and $\mathrm{Fe}(\mathrm{III})$ containing phyllosilicates as the electron donor or acceptor, including the Alphaproteobacterium Bradyrhizobium sp, Betaproteobacteria C. necator and R. solanacearum, and Deltaproteobacterium $G$. toluenoxydans. The recovery of a Geobacter species as an agent of Fe(III) reduction at Shovelers Sink is not surprising, as members of the Geobacteraceae often dominate soil and sediment $\mathrm{Fe}$ (III)-reducing microbial populations (Lovley et al., 2004), and multiple species in this family are known to reduce structural Fe(III) in phyllosilicates (Lovley et al., 1998; Kostka et al., 1999; Kashefi et al., 2008; Shelobolina et al., 2008). Geobacter sp. dominated both, smectite and HFO containing enrichment cultures and therefore was well adjusted to using both $\mathrm{Fe}$ (III)-bearing phases as the electron acceptor. Although a previous study (Kashefi et al., 2008) suggested that phyllosilicate-Fe(III)-reducing and Fe(III) (hydr)oxide-reducing microbial populations may not always overlap, no specific agents adjusted to using one or another solid phase Fe(III) were recovered at Shovelers Sink.

The microorganisms recovered as potential agents of phyllosilicate-Fe(II) oxidation are all common rhizosphere bacteria. Bradyrhizobium spp. are well-known as $\mathrm{N}_{2}$ fixing bacteria that form a symbiotic relationship with plants, especially soybeans, and are widely utilized in agriculture (Hume and Blair, 1992). In contrast, $R$. solanacearum is a soil-born plant pathogen causing leaf wilting in tomato, pepper, and potato plants as well as many other plant species (Denny, 2005). C. necator (including former

\section{REFERENCES}

Altschul, S. F., Gish, W., Miller, W., Myers, E. W., and Lipman, D. J. (1990). Basic local alignment search tool. J. Mol. Biol. 215, 403-410.

Amonette, J. E. (2002). "Iron redox chemistry of clays and oxides: environmental applications," in Electrochemical Properties of Clays, ed. A. Fitch (Aurora, CO: The Clay Minerals Society), 90-147.
Armstrong, W. (1978). “Root aeration in the wetland condition," in Plant Life in Anaerobic Environments, eds D. Hook and R. Crawford (Ann Arbor, MI: Ann Arbor Science Publishers Inc.), 269-297.

Barclay, A. M., and Crawford, R. (1983). The effect of anaerobiosis on carbohydrate-levels in storage tissues of wetlands plants. Ann. Bot. 51, 255-259.

Blöthe, M., and Roden, E. E. (2009). Microbial iron redox cycling in

Ralstonia eutropha strains) is a versatile soil bacterium known as an aromatic and chloroaromatic compounds degrader and a non-obligate bacterial predator of the bacteria and fungi (Makkar and Casida, 1987; Lykidis et al., 2010).

Various strains of Bradyrhizobium spp. and $C$. necator $(R$. eutropha) can grow autotrophically with $\mathrm{H}_{2}$ as the electron donor (Bowien and Kusian, 2002; Schwartz et al., 2003; Franck et al., 2008). In addition, a B. japonicum strain USDA110 is capable of thiosulfate-based chemolithotrophy (Masuda et al., 2010). None of phytopathogenic $R$. solanacearum strains were reported to grow autotrophically (Palleroni and Doudoroff, 1971). However, a recently recovered Ralstonia sp. strain HM08-01, 98\% similar to $R$. solanacearum, can oxidize soluble Fe(II) under microaerophilic conditions (Swanner et al., 2011). Our studies suggest a new role for these common rhizosphere bacteria, i.e., oxidation of structural $\mathrm{Fe}(\mathrm{II})$ in phyllosilicates. Further research with chemically defined substrates, such as $\mathrm{FeCl}_{2}$ and $\mathrm{Fe}(\mathrm{II})-\mathrm{NTA}$, is required to determine exact stoichiometry of $\mathrm{Fe}(\mathrm{II})$ oxidation by Shovelers Sink isolates.

The importance of native Fe(III) phyllosilicates as an electron acceptor for organic matter oxidation coupled to dissimilatory $\mathrm{Fe}$ (III) reduction in soils and sediments has been increasingly recognized (Kukkadapu et al., 2006; Stucki and Kostka, 2006; Komlos et al., 2008; Dong et al., 2009). In contrast, the role of microbial catalysis in phyllosilicate-Fe(II) oxidation has not received much attention, and to date only one organism is known to carry-out this reaction (Shelobolina et al., 2003). Our work thus significantly expands the range of organisms known to participate in phyllosilicate-Fe(II) oxidation. The ability of common rhizosphere bacteria to carry-out this process has significant implications not only for phyllosilicate-Fe redox geochemistry, but also for phyllosilicates diagenesis, e.g., low-temperature microbially driven smectite-to-illite transition, that may accompany Fe cycling in smectite and affect plant nutrition (Shen and Stucki, 1994; Stucki, 2011).

\section{ACKNOWLEDGMENTS}

With thank Cynthia A. Stiles and Matilde M. Urrutia from UWMadison Soil Science Department for introducing us to the Shovelers Sink site. This research was supported by the U.S. Department of Energy (DOE), Office of Biological and Environmental Research (BER) Subsurface Biogeochemical Research (SBR) Program through grant ER64172-1027487-001191; and the SBR Scientific Focus Area (SFA) at the Pacific Northwest National Laboratory (PNNL).

a circumneutral-pH groundwater seep. Appl. Environ. Microbiol. 75, 468-473.

Bowien, B., and Kusian, B. (2002). Genetics and control of $\mathrm{CO}_{2}$ assimilation in the chemoautotroph Ralstonia eutropha. Arch. Microbiol. 178, 85-93.

Bradbury, K. R. (ed.). (2001). Springs, sinks, and flowing wells: hydrogeology at the urban fringe. Midwest Ground Water Conference, 46th Annual Meeting,
Field Trip Guide, Madison WI.

Brady, N., and Weil, R. (2008). The Nature and Properties of Soils. Upper Saddle River, NJ: Prentice Hall.

Clayton, L., and Attig, J. W. (eds). (1997). Pleistocene Geology of Dane County, Wisconsin. Madison, WI: Wisconsin Geological and Natural History Survey.

Denny, T. P. (2005). "A short history of the biochemical and genetic research on Ralstonia solanacearum 
pathogenesis," in Bacterial Wilt Disease and the Ralstonia solanacearum Species Complex, eds P. P. C. Allen, and A. C. Hayward (St. Paul, MN: APS Press), 323-334.

Dong, H., Jaisi, D. P., Kim, J., and Zhang, G. (2009). Microbe-clay mineral interactions. Am. Mineral. 94, 1505-1519.

Emerson, D., Fleming, E. J., and Mcbeth, J. M. (2010). Iron-oxidizing bacteria: an environmental and genomic perspective. Annu. Rev. Microbiol. 64, 561-583.

Franck, W. L., Chang, W. S., Qiu, J., Sugawara, M., Sadowsky, M. J., Smith, S. A., and Stacey, G. (2008). Wholegenome transcriptional profiling of Bradyrhizobium japonicum during chemoautotrophic growth. J. Bacteriol. 190, 6697-6705.

Gee, G. W., and Bauder, J. W. (1986). "Particle-size analysis," in Methods of Soil Analyses. Physical and Mineralogical Methods, ed. A. Klute (Madison: American Society of Agronomy; Soil Science Society of America), 386-411.

Hobbie, J. E., Daley, R. J., and Jasper, S. (1977). Use of nuclepore filters for counting bacteria by fluorescence microscopy. Appl. Environ. Microbiol. 33, 1225-1228.

Hume, D. J., and Blair, D. H. (1992). Effect of numbers of Bradyrhizobium japonicum applied in commercial inoculants on soybean seed yield in Ontario. Can. J. Microbiol. 38, 588-593.

Hungate, R. E. (1968). A roll tube method for cultivation of strict anaerobes. Methods Microbiol. 3B, 117-132.

Jackson, M. L. (1969). Soil Chemical Analysis - Advanced Course, 2nd Edn. Madison: University of Wisconsin.

Jorgensen, K. S., and Tiedje, J. M. (1993). Survival of denitrifiers in nitrate-free, anaerobic environments. Appl. Environ. Microbiol. 59, 3297-3305.

Kashefi, K., Shelobolina, E., Elliott, W. C., and Lovley, D. R. (2008). Growth of thermophilic and hyperthermophilic Fe (III)-reducing microorganisms on a ferruginous smectite as the sole electron acceptor. Appl. Environ. Microbiol. 74, 251-258.

Keeling, J. L., Raven, M. D., and Gates, W. P. (2000). Geology and characterization of two hydrothermal nontronites from weathered metamorphic rocks at the Uley graphite mine, South Australia. Clays Clay Miner. 48, 537-548.

Komadel, P., and Stucki, J. W. (1988). Quantitative assay of minerals for $\mathrm{Fe}^{2+}$ and $\mathrm{Fe}^{3+}$ using 1,10phenanthroline: III. A rapid photochemical method. Clays Clay Miner. 36, 379-381.

Komlos, J., Peacock, A., Kukkadapu, R. K., and Jaffé, P. R. (2008). Longterm dynamics of uranium reduction/reoxidation under low sulfate conditions. Geochim. Cosmochim. Acta 72, 3603-3615.

Konhauser, K. O., Kappler, A., and Roden, E. E. (2011). Iron in microbial metabolisms. Elements 7, 89-93.

Kostka, J. E., Wu, J., Nealson, K. H., and Stucki, J. W. (1999). The impact of structural $\mathrm{Fe}$ (III) reduction by bacteria on the surface chemistry of smectite clay minerals. Geochim. Cosmochim. Acta 63, 3705-3713.

Kukkadapu, R. K., Zachara, J. M., Fredrickson, J. K., Mckinley, J. P., Kennedy, D. W., Smith, S. C., and Dong, H. (2006). Reductive biotransformation of $\mathrm{Fe}$ in shalelimestone saprolite containing $\mathrm{Fe}(\mathrm{III})$ oxides and $\mathrm{Fe}(\mathrm{II}) / \mathrm{Fe}(\mathrm{III})$ phyllosilicates. Geochim. Cosmochim. Acta 70, 3662-3676.

Kunapuli, U., Jahn, M. K., Lueders, T., Geyer, R., Heipieper, H. J., and Meckenstock, R. U. (2010). Desulfitobacterium aromaticivorans $\mathrm{sp}$ nov and Geobacter toluenoxydans sp. nov., iron-reducing bacteria capable of anaerobic degradation of monoaromatic hydrocarbons. Int. J. Syst. Evol. Microbiol. 60, 686-695.

Lovley, D. R., Chapelle, F. H., and Woodward, J. C. (1994). Use of dissolved $\mathrm{H}_{2}$ concentrations to determine distribution of microbially catalyzed redox reactions in anoxic groundwater. Environ. Sci. Technol. 28, 1205-1210.

Lovley, D. R., Fraga, J. L., BluntHarris, E. L., Hayes, L. A., Philips, E. J. P., and Coates, J. D. (1998). Humic substances as a mediator for microbially catalyzed metal reduction. Acta Hydrochim. Hydrobiol. 26, 152-157.

Lovley, D. R., and Goodwin, S. (1988). Hydrogen concentrations as an indicator or the predominant terminal electron-accepting reactions in aquatic sediments. Geochim. Cosmochim. Acta 52, 2993-3003.

Lovley, D. R., Holmes, D. E., and Nevin, K. P. (2004). Dissimilatory Fe(III) and $\mathrm{Mn}(\mathrm{IV})$ reduction. Adv. Microb. Physiol. 49, 219-286.

Lovley, D. R., and Phillips, E. J. P. (1986). Organic matter mineralization with reduction of ferric iron in anaerobic sediments. Appl. Environ. Microbiol. 51, 683-689.

Lovley, D. R., and Phillips, E. J. P. (1988). Novel mode of microbial energy metabolism: organic carbon oxidation coupled to dissimilatory reduction of iron or manganese. Appl. Environ. Microbiol. 54, 1472-1480.

Lykidis, A., Perez-Pantoja, D., Ledger, T., Mavromatis, K., Anderson, I. J., Ivanova, N. N., Hooper, S. D., Lapidus, A., Lucas, S., Gonzalez, B., and Kyrpides, N. C. (2010). The complete multipartite genome sequence of Cupriavidus necator JMP134, a versatile pollutant degrader. PLoS ONE 5, e9729. doi:10.1371/journal.pone.0009729

Makkar, N. S., and Casida, L. E. (1987). Cupriavidus necator gen. nov., sp. nov: a nonobligate bacterial predator of bacteria in soil. Int. J. Syst. Bacteriol. 37, 323-326.

Masuda, S., Eda, S., Ikeda, S., Mitsui, H., and Minamisawa, K. (2010). Thiosulfate-dependent chemolithoautotrophic growth of Bradyrhizobium japonicum. Appl. Environ. Microbiol. 76, 2402-2409.

Mehra, O. P., and Jackson, M. L. (1980). Iron oxide removal from soils and clays by a dithionitecitrate system buffered with sodium bicarbonate. Clays Clay Miner. 7, 317-327.

Miller, T. L., and Wolin, M. J. (1974). A serum bottle modification of the Hungate technique for cultivating obligate anaerobes. Appl. Microbiol. 27, 985-987.

Muyzer, G., Teske, A., Wirsen, C. O., and Jannasch, H. W. (1995). Phylogenetic relationships of Thiomicrospira species and their identification in deep-sea hydrothermal vent samples by denaturing gradient gel electrophoresis of $16 \mathrm{~S}$ rDNA fragments. Arch. Microbiol. 164, 165-172.

Palleroni, N. J., and Doudoroff, M. (1971). Phenotypic characterization and deoxyribonucleic acid homologies of Pseudomonas solanacearum. J. Bacteriol. 107, 690-696.

Schmidt, C., Behrens, S., and Kappler, A. (2010). Ecosystem functioning from a geomicrobiological perspective a conceptual framework for biogeochemical iron cycling. Environ. Chem. 7, 399-405.

Schwartz, E., Henne, A., Cramm, R., Eitinger, T., Friedrich, B., and Gottschalk, G. (2003). Complete nucleotide sequence of pHG1: a Ralstonia eutropha H16 megaplasmid encoding key enzymes of H2-based lithoautotrophy and anaerobiosis. J. Mol. Biol. 332, 369-383.

Shelobolina, E. C., Vrionis, H., Findlay, R. H., and Lovley, D. R. (2008). Geobacter uraniireducens sp. nov., isolated from subsurface sediment undergoing uranium bioremediation. Int. J. Syst. Evol. Microbiol. 58, 1075-1079.

Shelobolina, E. S., Anderson, R. T., Vodyanitskii, Y. N., Sivtsov, A. M., Yuretich, R., and Lovley, D. R. (2004). Importance of clays size minerals for $\mathrm{Fe}(\mathrm{III})$ respiration in a petroleum-contaminated aquifer. Geobiology 2, 67-76.

Shelobolina, E. S., Gaw Vanpraagh, C., and Lovley, D. R. (2003). Use of ferric and ferrous iron containing minerals for respiration by Desulfitobacterium frappieri. Geomicrobiol. J. 20, 143-156.

Shelobolina, E. S., Nevin, K. P., Blakeney-Hayward, J. D., Johnsen, C. V., Plaia, T. W., Krader, P., Woodward, T., Holmes, D. E., Vanpraagh, C. G., and Lovley, D. R. (2007). Geobacter pickeringii sp. nov., Geobacter argillaceus sp. nov. and Pelosinus fermentans gen. nov., sp. nov., isolated from subsurface kaolin lenses. Int. J. Syst. Evol. Microbiol. 56, 126-135.

Shen, S., and Stucki, J. W. (1994). "Effects of iron oxidation state on the fate and behavior of potassium in soils," in Soil Testing: Prospects for Improving Nutrient Recommendations, eds J. L. Havlin and J. Jacobsen (Madison, WI: Soil Science Society of America), 173-185.

Stookey, L. L. (1970). Ferrozine - a new spectrophotometric reagent for iron. Anal. Chem. 42, 779-781.

Straub, K. L., Benz, M., Schink, B., and Widdel, F. (1996). Anaerobic, nitrate-dependent microbial oxidation of ferrous iron. Appl. Environ. Microbiol. 62, 1458-1460.

Stucki, J. (2011). A review of the effects of iron redox cycles on smectite properties. C. R. Geosci. 343, 199-209.

Stucki, J. W. (1981). The quantitative assay of minerals for $\mathrm{Fe}^{2+}$ and $\mathrm{Fe}^{3+}$ using 1,10-phenanthroline: II. A photochemical method. Soil Sci. Soc. Am. J. 45, 638-641.

Stucki, J. W., and Kostka, J. E. (2006). Microbial reduction of iron in smectite. C. R. Geosci. 338, 468-475.

Swanner, E. D., Nell, R. M., and Templeton, A. S. (2011). Ralstonia species mediate Fe-oxidation in circumneutral, metal-rich subsurface fluids of Henderson mine, CO. Chem. Geol. 284, 339-350.

Weber, K. A., Achenbach, L. A., and Coates, J. D. (2006). Microorganisms pumping iron: anaerobic microbial iron oxidation and reduction. Nat. Rev. Microbiol. 8, 100-113.

Weber, K. A., Picardal, F. W., and Roden, E. E. (2001). Microbially- 
catalyzed nitrate-dependent oxidation of biogenic solid-phase $\mathrm{Fe}$ (II) compounds. Environ. Sci. Technol. 35, 1644-1650.

Woomer, P. L. (1994). "Microbiological and biochemical properties," in Methods of Soil Analysis. Part 2, ed. J. M. Bigham (Madison, WI: Soil Science Society of America), 59-79.
Conflict of Interest Statement: The authors declare that the research was conducted in the absence of any commercial or financial relationships that could be construed as a potential conflict of interest.

Received: 09 December 2011; accepted: 21 March 2012; published online: 04 April 2012.
Citation: Shelobolina E, Konishi $H$, $X u$ H, Benzine J, Xiong MY, Wu T, Blöthe M and Roden E (2012) Isolation of phyllosilicate-iron redox cycling microorganisms from an illite-smectite rich hydromorphic soil. Front. Microbio. 3:134. doi: 10.3389/fmicb.2012.00134

This article was submitted to Frontiers in Microbiological Chemistry, a specialty of Frontiers in Microbiology.
Copyright () 2012 Shelobolina, Konishi, Xu, Benzine, Xiong, Wu, Blöthe and Roden. This is an open-access article distributed under the terms of the Creative Commons Attribution Non Commercial License, which permits non-commercial use, distribution, and reproduction in other forums, provided the original authors and source are credited. 